\title{
Komplexní monografie
}

\author{
Ivo Pospíšil (Brno)
}

Libor Martinek: Wilhelm Przeczek (monografie). Wrocław: Oficyna Wydawnicza ATUT, 2018. 424 s. ISBN 978-83-7977360-2.

Dlouho jsem tuto rozsáhlou, reprezentativní knihu četl, promýšlel, ale musím již na počátku předznamenat, že nejsem polonista ani se vysloveně nezabývám tzv. menšinovou literaturou, i když o ní někdy také píšu a její aspekt beru v úvahu a někdy i o něm něco malého napíšu, nejsem ani odborník na česko-polské vztahy, i když se jich často dotýkám. Na Slovensku se menšinovým aspektem literatury zabývá několik badatelů, z nich si dovolím jmenovat jen Petra Andrušku nebo jeho žáka Patrika Šenkára; u nás se takto etabloval naprríklad Libor Martinek, pracovník Slezské univerzity v Opavě a mimořádný profesor Vratislavské univerzity (dříve hlavní město českého Slezska, nynější Wrocław, jako součást Pruska a Německa se jmenovalo Breslau): zde také tato kniha o polském básníkovi, prozaikovi a dramatikovi česky vychází.

Martinek je znám jako autor řady publikací, který se právě kulturním areálem Slezska a polsko-českými vztahy systematicky zabývá, a to nejen jako literární kritik, historik a teoretik-komparatista, ale také jako básník, překladatel a v neposlední řadě i vydavatel, např. Polská literatura českého Těsinska po roce 1945 (Opava, 2004), Polská poezie čského Těšinska po roce 1920 (Opava, 2006), Region, regionalismus a regionálni literatura (Opava, 2007), Życie literackie na Zaolziu 1920-1989 (Kielce, 2008), Identita v literatuře čského Těšinska. Vybrané problémy (Opava, 2009), monografie o Henryku Jasiczkovi, Óndrovi Łysohorském a Władyslawu Sikorovi aj. Je nositelem tolika vyznamenání od nás i z Polska (včetně ceny rektora vratislavské univerzity, ceny primátora Varšavy a polského ministerstva kultury aj.), že je ani nelze všechny vypsat. Przeczek byl tvůrce složitého osudu a Martinek ho bere organicky jako součást osudů českého Těšínska, čes- ko-polských vztahů a komplikovaných dějin 20 . století. Přitom neredukuje ani skutečně poetologické a literárněkritické aspekty. jež taková monografie má mít. Przeczek spojil svůj život s levicovým hnutím, které jej však zklamalo: dvacet let nesměl v Československu publikovat za podporu reformistického hnutí konce šedesátých let minulého století a za odsouzení invaze pěti států Varšavské smlouvy 21. 8. 1968. V tomto smyslu byl jeho život - zejména jeho druhá polovina tragický. Nicméně vždy si dovedl najít vhodnou plochu k publikační činnosti, kterou mu zčásti poskytovalo Polsko i v dvacetiletí 1969-1989. V tom mu pomohla jeho všestrannost: básník, prozaik, dramatik, autor rozhlasových her, literatury pro děti, překladatel, autor esejů, aforismů a epigramů (Poláci pro ně mají termín „fraszka“, který Martinek používá i v českém textu). Podstatnou součástí rozsáhlé monografie a také publikace části Przeczkovy korespondence, z níž mimo jiné vyniká korespondence s Jindřichem Zogatou, básníkem a prozaikem žijícím v Brně, která zabírá poměrně dlouhou dobu (1981-1992) a obsahuje peripetie charakteristické pro básníkovy osobní poměry, ale také reflektující temnou politickou atmosféru, kdy však už začíná pomalu rozednívat. Oba básníci byli politicky odsunuti na vedlejší kolej, bylo jim dlouho zakázáno publikovat a to oba postihlo a vlastně jim zničilo část života.

Martinkův postup je primárně literárněhistorický, ale také literárněteoretický, literárněkritický, recepční a komparatistický. Je to vskutku komplexní analýza i syntéza, které neopomíjejí z Przeczkova díla nic podstatného, ukazují i na jeho překlady do češtiny i Przeczkovy překlady české literatury. Sám Martinek, stejně jako Zogata jsou ostatně vynikajícími překladateli 
jeho poezie. Kontaktologické srovnávání je Martinkovou doménou. Je to o to těžší a zrádněǰší, že se musí pohybovat na poměrně bahnité půdě a v delikátních souvislostech česko-polských vztahů, které nebyly a nejsou - oproti některým tvrzením - nijak idylické. Jsou zde dvě úskalí, s nimiž se autor, zdůrazňující klady těchto vztahů, poměrně slušně vyrovnává: česko-polský aspekt a jeho kontroverznost a pozice polské menšinové literatury v Polsku v rámci polské literatury jako takové. Snad by knize neuškodilo, kdyby se autor více věnoval právě kontroverzním polohám této látky, nebot i to nebo hlavně to patří k literární komparatistice a recepční estetice. Martinek zachází se složitou problematikou a rozsáhlým dílem důkladně a navíc je dokáže vyložit srozumitelně, přehledně, seriózně a odborně. Ona syntéza přístupů, čtivosti, odbornosti a invenčnosti s pozadím kulturních vztahů dvou národů na širším horizontu střední Evropy činí z Martinkovy knihy nepominutelný opus.

\section{prof. PhDr. Ivo Pospišil, DrSc.}

Ústav slavistiky

Filozofická fakulta, Masarykova univerzita

Arna Nováka 1, 60200 Brno, Česká republika

ivo.pospisil@phil.muni.cz 